\title{
Rubber agroforestry system in Indonesia: Past, present, and future practices
}

\author{
D.S. Agustina* and Fetrina Oktavia \\ Indonesian Rubber Research Institute
}

\begin{abstract}
Indonesia is the second largest rubber producing country after Thailand. The area of rubber in 2018 was about 3.7 million hectares with the total production of 3.6 million tons. Among those areas, $88.13 \%$ were owned by smallholders, and the rest belongs to private estate $(5.16 \%)$ and government estate $(6.7 \%)$. Productivity is still become the problem at smallholders' level. Some efforts have been conducted in order to improve the productivity of smallholders. The concept of agroforestry has become increasingly relevant in recent days as they introduced new commercial opportunities to smallholders. Agroforestry, with its multiple environmental and economic benefits, can help the agriculture and forestry sectors find innovative solutions to present-day problems: including low profitability, environmental impacts, and negative public perception This paper presents the implementation of rubber agroforestry system at the smallholders' level since the past, current situation and future scenario for agroforestry in order to support the sustainability of rubber smallholders.
\end{abstract}

Keywords: Agroforestry, rubber, smallholders

\section{Introduction}

Indonesia is the second largest rubber producing country in the world after Thailand. In 2018, Indonesia contributed $26 \%$ to the world's rubber production while Thailand contributed $36 \%$ and the rest were contributed by other countries such as Vietnam, Malaysia, India, China and others. The area of rubber in Indonesia in 2018 was about 3.7 million hectares with the total production of 3.6 million tons. Among those areas, $88.13 \%$ were owned by smallholders, and the rest belongs to private estate $(5.16 \%)$ and government estate (6.7\%) [1].

Productivity is still a problem at smallholders' level. This is due to several factors, including the low level of clone adoption at the farm level, lack of garden maintenance, and old/damaged rubber areas that need to be replanted. In 2018, the productivity of smallholders in Indonesia was 1,1 ton/ha/year, lower compare to the private and government estate which has reached 1,5 ton/ha/year. Rubber area were spread all over the country. South Sumatra is the largest rubber Province in Indonesia with the area of rubber was about 1.3 million ha in 2019 and the production almost 1,2 million ton [2].

\footnotetext{
* Corresponding author: dwishinta_sbw@yahoo.com
} 
Several efforts to improve productivity at the farm level have been carried out by the government through assisted projects such as the Nucleus Estate-Smallholder (NES), Replanting-Rehabilitation and Extension of Export Crops (RREEC), Smallholder Rubber Development (SRDP), Tree Crop Smallholder Development Projects (TCSDP) and Tree Crop Smallholder Sector (TCSS) projects. However, because government funds are also limited, it has not been able to reach all existing smallholder's areas.

Agribusiness of rubber is experiencing long unfavorable conditions. This is due to the declining of rubber price in the last few years as well as increasing the cost of production especially the cost of tapping. Rubber price has reached the highest peak in 2011, but since 2012-2016 it has continued to decline to the low level of USD 1.38 per $\mathrm{kg}$. In early 2017 , rubber price reached USD 2.2 but in June 2017 rubber price was again hit toward the lowest level at USD 1.43 per $\mathrm{kg}$. It continues to decline and in 2020 the rubber price has reached 1.32 USD per kg (SICOM, 2020). The average price fluctuation of Technical Specified Rubber (TSR) 20 since 1998 to 2020 is shown in Figure 1.

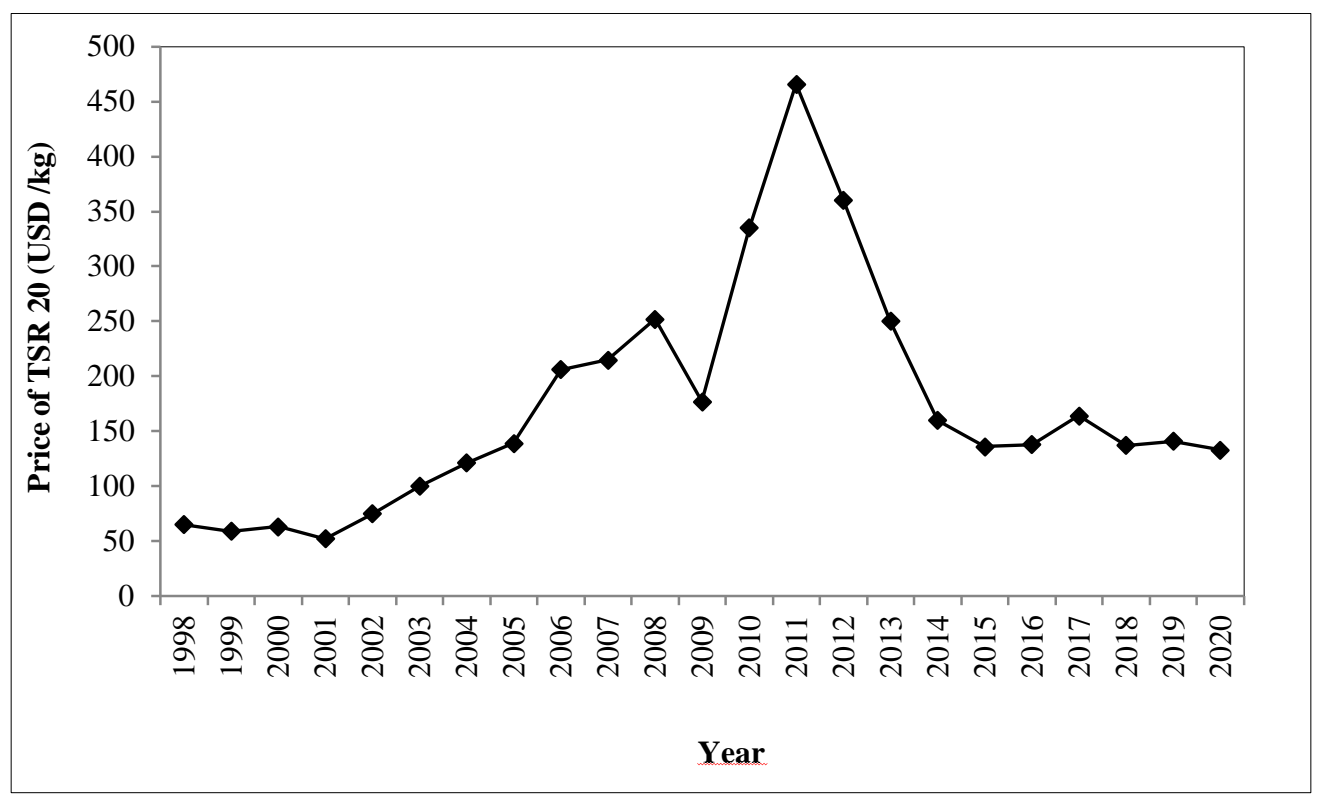

Fig. 1. The average rubber price fluctuation $(1998-2020)$

The decrease of rubber price has affected the socio economic of smallholders especially in South Sumatra. Syarifa et al. (2015) recorded some socio economic impacts of the decline of rubber price as the decline in farmer's income, the decline of investment ability of smallholders, the decline of purchasing power of smallholders, and the changing of source of income to other than rubber. Some efforts have been taken to address the issue of low rubber price at smallholders' level such as: 1) increase smallholders' income by planting high yielding clones together with intercropping to provide an additional income for smallholders, and 2) improve the quality of raw rubber material from smallholders through the organized marketing system.

The concept of agroforestry has become increasingly relevant in recent days as they introduced new commercial opportunities to smallholders. Agroforestry, with its multiple environmental and economic benefits, can help the agriculture and forestry sectors find innovative solutions to present-day problems: including low profitability, environmental impacts, and negative public perception This paper presents the implementation of rubber 
agroforestry system at the smallholders' level since the past, current situation and future scenario for agroforestry in order to support the sustainability of rubber smallholders.

\section{Agroforestry system in Indonesia}

Rubber agroforestry system has been implemented by smallholders since a long time ago. There are some types of agroforestry system that has been established at the smallholder's level, namely: 1) jungle rubber, 2) Long-term rubber-based agroforestry with perennial crops (Shorea, teak, coffee, cocoa, etc.) 3) Rubber-based agroforestry with food crops (banana, sugarcane, pineapple, rice, chilli, tubers, etc.) during immature period ; 4) Double rows of rubber trees separated by wide spacing for food intercrops. Double rows spacing is not a common practice at the smallholders' level, but in the current situation where the rubber price is low, this type of agroforestry system is suitable to be adopted by smallholders.

Rubber has been developed in Indonesia since more than a century and since then Indonesia has had the largest rubber area in the world. Most of rubber area were owned by smallholders with an average 2 hectares of rubber area per family. The jungle rubber concept is familiar with smallholders where they plant rubber with unselected seedling material with low productivity mixed with timber trees (forest re-growth), fruit trees, and different annual crops during immature period.

The practices of jungle rubber gave advantages to smallholders such as no cost, no labor required for maintenance during immature period; and additional income from fruits, timber, and other non-timber forest products harvested from the agroforest. Although rubber tapping was delayed compared to rubber monoculture on estates, yields still provided an attractive income for smallholders. Indirect environmental benefits from jungle rubber included soil conservation and rehabilitation of degraded lands [7].

With rapid deforestation taking place in Sumatra (since 1970's), rubber agroforests are becoming the most important forest-like vegetation that we can find covering substantially large areas in the lowlands (Joshi et al. 2002). It has become a major reservoir of forest species itself and provides connectivity between forest remnants for animals that need larger ranges than the forest remnants provide. While jungle rubber could not replace natural forest in terms of conservation value, the question whether such a production system could contribute to the conservation of forest species in a generally impoverished landscape is very relevant. Jungle rubber provides a major reservoir of forest species itself and provides connectivity between forest remnants for animals that need larger ranges than the forest remnants provide. The study conducted by Beukema and van Noordwijk (1995) found that the average plot level species richness was not significantly different amongst forest, jungle rubber and rubber plantations, however at the landscape level the species-area curve for jungle rubber had a significantly higher slope parameter, indicating higher beta diversity.

From all plants abundant in traditional jungle rubber, be it spontaneous ones or managed ones, mostly include timber and non-timber plants. Timber uses are divided into fuelwood as well as house construction and furniture. Non-timber uses include edible ones (i.e., fruits and vegetables) [7]. About two-thirds of all species present in rubber agroforestry systems have one or more uses. The yield of rubber in the jungle rubber system is low because of the use of unselected planting material. In the quest for yield increases of rubber gardens, it is therefore important to search for the systems providing optimal growing conditions for improved rubber varieties, but still allowing a major part of the biodiversity.

From 1994 to 2007, World Agroforestry Centre (ICRAF) in association with CIRADFrance and Indonesian Rubber Research Institute (Sembawa Research Station) established a network of trials to study rubber agroforestry systems and test different approaches suitable for different conditions under SRAP (Smallholder Rubber Agroforestry Project). The project was funded by various funding agencies such as: USAID, French Embassy, Gapkindo, and 
CFC (the Common Fund for Commodities) [6, 11]. This project was established in Jambi, West Sumatra, and West Kalimantan.

The network on-farm trials were developed from 1994 to 2007. The basic assumption/ hypothesis of the project was to increase the productivity of jungle rubber in Indonesia that could be attained by providing improved planting materials of the tree components to the farmers and evaluating which are the most appropriate and affordable for smallholders. Three rubber agroforestry systems (RAS) have been tested in some Provinces, include South Sumatra, West Sumatra, Jambi, and West Kalimantan. The trials, with an average of 3 to 5 farms or replications per trial, covering 100 hectares and involving about 150 farmers have been established. Each farmer's field is considered as a replication with 1 or 2 simple treatments such as: rubber weeding levels, rubber fertilization, rice variety $\mathrm{x}$ fertilization, type of associated trees, and types of cover crops (Multi Purposes Trees (MPT)/Fast Growing Trees (FGT)) combination. These experiments take into account the limited resources of smallholders. Labor is one the main factors being considered in assessment of a system's suitability.

RAS 1 is similar with the current jungle rubber system, in which unselected rubber seedlings are replaced by adapted clones. Vegetations in between rubber rows are expected to be kept by farmer in order to conserve certain level of biodiversity. The main objectives are to determine if clonal rubber germplasm succeed to grow well under jungle rubber environment, to increase yields significantly, and to assess the minimum required management level of RAS. A secondary objective is to assess the level of biodiversity conservation in the jungle rubber system. It is expected that the rubber clones be able to compete with the natural secondary forest growth.

RAS 2, is a complex agroforestry system in which rubber and perennial timber and fruit trees are established after slashing and burning, at a density of 550 rubber and a range of $90 / 250$ other perennial trees per hectare. It is very intensive, with annual crops being intercropped during the first 2-3 years, with emphasis on improved upland varieties of rice, with various levels of rice fertilization.

RAS 3, planted only in West Kalimantan, intend to provide solution to fields invaded by Imperata. It is also a complex agroforestry system with rubber and other trees planted at the same density as that as in RAS 2, but with no intercrops except in the forst year, followed by a combination of leguminous cover crops, and fast growing trees (FGT). It is established on degraded lands covered by alang-alang grass (Imperata cylindrica) [5]. The grass bounds the growth of annual crops so selected cover crops (Mucuna, Flemingia, Crotalaria) or MPTs (Calliandra, Wingbean, Gliricidia) and FGTs ( G. arborea, P. falcataria., A. mangium) are established with various density between 50-110 trees/ha. It had been assumed that the FGT could be harvested in 7 or 8 years to provide timber and wood for the existing pulp industry. The objective of RAS 3 is to reduce the weeding requirement by providing a favorable environment for rubber and the associated trees to grow, cover the soil as soon as possible to bound Imperata growth. The clones tested were PB260, BPM1, RRIC100, and RRIM 600 that proves to be adapted.

The performance of clones in RAS1 environments is encouraging and shows that rubber could grow well and could adapted under the limited weeding activity. Compared to seedling originated plants, all clones perform better in term of growth since the beginning of the establishment. Up to 40 months, among clones, BPM 1 has the best growth followed by other clones, and seedling growth was the slowest. After 40 months, due to white root disease attack on BPM 1 and RRIM 600, the growth of those two clones was reduced and the growth of the other two clones RRIC 100 and PB 260 was very good and ready to be tapped at 5 years. However, the seedling originated plant can be tapped at about 5.5 years after planting. The frequencies of weeding (in rubber rows) of the plots in this trial were between 3-4 times per year. 
Farmer already realize that the growth of rubber will be reduced due to competition with other vegetation. In West Kalimantan, farmers did not follow entirely the protocol of trials and did adapt to local conditions. They slash the vegetation in intra-rows since the second year (once a year) with only few tree species kept especially those plants that have economic value. These activites result in slower rubber growth (compared to Jambi) and no significant difference of rubber growth was observed due to weeding level. The effects of perennial intercrops on rubber growth vary from year to year, except for treatment with durian, there is no significant difference observed due to intercrops, at 54 months. However, difference rubber performance was due more by sites/farmers participant of the trial rather than by different intercrops. Due to shading of the trees, those fruit trees cannot produce fruit as good as fruit-trees planted in open areas.

The RAS 2 trials in West Kalimantan were not as intensive as it was expected. The farmers only practices the annual intercrops (upland rice mainly) during the first two years. It is also clear that if the spacing of rubber is $6 \mathrm{~m} \mathrm{x} 3 \mathrm{~m}$, planting perennial plant under rubber is not encouraging in term of the fruit production

For RAS 3: The creeping legumes were clearly the top performers in controlling Imperata. Pueraria was slightly better than Mucuna for rubber growth (statistically significant). Both Pueraria and Mucuna grew well and managed to suppress re-growth of Imperata. However, the creeping legumes required to be 'weeded' regularly from the rubber rows as they entangled the trees. While among the erect legumes, Flemingia was good for rubber; but Crotalaria proved disappointing. Rubber trees with no cover crops but with Imperata or Chromolaena had not yet reached tapping size. This finding is consistent with earlier work done in Sembawa Research Station where it took over 10 years for rubber trees without proper Imperata control [10]. All FGT were relatively successful in controlling Imperata re-growth

Implementing participatory trials need a close relationship and continuous communication with farmers. Planning, implementing and modifying the trials have to be carried out under close discussion with farmers. Trust building between researchers and farmers is needed since the beginning of the activity, in order to achieve the objective of the on-farm trial. Once the trust is built, then the following programs and activities could be carried out more efficiently. It is very common that farmers do not follow all protocols that were designed and fixed previously together with the researchers. This kind of situations is observed both in Jambi and in West Kalimantan. Again, a close relationship with farmers and try to understand why they do not follow the protocol is one of the tasks of the on-farm participatory trials. Intensive discussion is important to choose better technical options that adapted to farmers' needs. The trade-off between inputs (fertilisers, labours, chemicals) and growth or plant diversity is always of interest of most peoples [7]. Due to many constraints faced by farmers, especially cash money for most Indonesian farmers, they have to choose between spending money and allocating family labours. The maximum rubber growth is not always the objective of farmers in establishing various RAS when the most critical factor is cost of maintenance during immature period. The critical question is how providing technology options to farmers considering their labor constraints and capital opportunities.

In the current situation where rubber price is still fluctuated, the practice of rubber agroforestry system is very beneficial, especially in order to increase the land productivity and additional income for smallholders. Sembawa Research Station has promoted the wide row spacing ( $18 \mathrm{~m} \times 2 \mathrm{~m})$ x 2,5 m. By using this wide row spacing, smallholders could plant intercrop between rubber with cash crop and or perennial crops for long period even until the replanting period of rubber. It was known that with the single row spacing system, the growth of rubber trees in the first tapping year was slightly better than with the double row spacing, but the differences were not significant [8]. 
Latex yield per tree with double row and single row system was similar, but the latex yield per hectare was significantly higher with double row spacing. The latex yield with single row/ planting distance $6 \mathrm{~m} \times 3 \mathrm{~m}$ (population 550 trees/ ha) and the double row system with planting distance $18 \mathrm{~m} \times(2 \times 2.5 \mathrm{~m})$ (400 trees/ ha). The light penetration in the areas between rows of eight-year-old rubber trees with single row system is not more than $30 \%$, whereas with double row systems it was $>80 \%$, measured at a distance of $4 \mathrm{~m}$ from the rubber tree rows. Technically, it is feasible to intercrop rubber trees with food crops. Economically, intercropping of rubber with food crops, with either single row or double row system, is profitable with Revenue and Cost $(\mathrm{R} / \mathrm{C})$ ratio of 1.86 and 1.93 , respectively. Therefore, it is feasible to grow food crops intercropped with rubber trees with the double row system, particularly for smallholders, with a Marginal Benefit Cost Ratio (MBCR)value of 2.07. Planting rubber with double row spacing of $18 \mathrm{~m} \times 2 \mathrm{~m}$ x $2.5 \mathrm{~m}$ is recommended for longer-term intercropping.

In this context, rubber-based agroforestry system (RAS) with rubber clonal material and efficient management practices appears as a more sustainable alternative compare to rubber monoculture. Rubber Agroforestry system could be a solution to improve the resilience of rubber smallholders in facing socio-economic (volatility of NR price) and environmental (climate change, erosion of biodiversity) issues. Conventional breeding programs are devoted to monospecific system. Researchers are confronted to biological and environmental constraints such as the long-term breeding cycle for perennial crops, and the adaptation to accelerating climate change. A participatory breeding programme with smallholders is expected to improve the resilience of rubber plantations. Some recommended clones already produced by Indonesian Rubber Research Institute

In the future, the agroforestry system should use the double row system mixed with high yielding planting materials. Some of the newest recommended clones produced by Indonesian Rubber Research are [12, 2]:

IRR 230, this is a latex timber clone with fast growth. The potential of latex production is about $2,008 \mathrm{~kg} / \mathrm{ha} / \mathrm{year}$. This clone is resistance to leaf fall disease, tolerant to tapping panel dryness (TPD), and response to stimulant. The latex produced suitable for SIR3CV, SIR3L, and RSS.

IRR 220, this is a latex clone with fast growth. The potential of latex is about 2,485 $\mathrm{kg} / \mathrm{ha} /$ year. This clone is resistance to leaf fall disease, tolerant to TPD, and response to stimulant. The latex produced can be processed to SIR3CV, SIR3L, and latex concentrate.

IRR 118, this is a latex clone with fast growth. The potential of latex production is about $2,200 \mathrm{~kg} / \mathrm{ha} /$ year. This clone is moderate resistance to leaf fall disease, tolerant to TPD, and response to stimulant. The latex produced suitable for SIR 3WF.

IRR 112, this is a latex clone with fast growth. The potential of latex production is about $2,542 \mathrm{~kg} / \mathrm{ha} /$ year. This clone is resistance to leaf fall disease, tolerant to TPD, and response to stimulant. The latex produced suitable for latex concentrate processing.

\section{Conclusion}

1. Rubber agroforestry system already practiced by smallholders since long time ago.

2. Rubber Agroforestry System (RAS) has shown good findings in terms of agronomic and socio economic aspects.

3. The practices of wide row spacing distancing could be implemented in the current situation where rubber price is still fluctuated.

4. In the future, the practice of Rubber Agroforestry system should integrated with high productivity recommended rubber clones from Indonesian Rubber Research Institute. 


\section{References}

1. Directorate General of Estate Crop. 2019. Tree Crop Estate Statistics of Indonesia 2018-2020 : Rubber. Directorate General of Estate Crops, Jakarta (2019).

2. Estate Crop Agency of South Sumatra Province, 2019. Statistical of Rubber 2019. Estate Crop Agency of South Sumatra (2019).

3. Lasminingsih, M. Sekar Woelan, and Aidi-Daslin. Evaluasi Keragaan Klon Karet IRR Seri 100. Pros. Lok. Nas. Pemuliaan Tanaman Karet 2009. p. 60-83(2009). [Bahasa Indonesia].

4. Laxman J, Wibawa, G., Vincent, G., Boutin, D., Akiefnawati, R., Manurung, G., van Noordwijk, M. and Williams, S.E. Jungle rubber: a traditional agroforestry system under pressure in Booklet ICRAF SEA. 38 p. ISBN 979-3198-04-4 (2002).

5. Penot E. Taking the jungle out of rubber. Improving rubber in Indonesian agroforestry systems. In Agroforestry Today (1995).

6. Penot, E. Stratégies paysannes et évolution des savoirs : l'hévéaculture agroforestière indonésienne. Thèse de doctorat. Faculté des Sciences Economiques. Montpellier, Université Montpellier I.: 360p (2001).

7. Penot, E., G. Wibawa, and B. Chambon. An History of Rubber Agroforestry Systems development in Indonesia and Thailand as alternative for a sustainable agriculture and income stability in Proceedings International Rubber Conference, IRRDB, Bali (2017).

8. Sahuri, Andi Nur Cahyo, Risal Ardika, Iman Satra Nugraha, Aprizal Alamsyah, and Nurmansyah. 2019. Journal of Tropical Crop Science. 6,1:50-59(2019).

9. Van Noordwijk M and Tomich T.P. Agroforestry technologies for social forestry: Tree crop interactions and forestry farmer conflicts. Social forestry and sustainable management, p. 168 -193. Jakarta (1995).

10. Wibawa, G. Rubber Based Agroforestry Research In Indonesia in Proceeding of Indonesian Rubber Conference and IRRDB Symposium. Bogor, 12-14 September 2000 (2001).

11. Wibawa G, Joshi L and van Noordwijk, M, Penot E. Rubber based Agroforestry systems (RAS) as Alternatives for Rubber Monoculture System. IRRDB Conference 2006 (2006).

12. Woelan, S., Aidi-Daslin, Mudji Lasminingsih, and Irwan Suhendry. Evaluasi Keragaan Klon Karet IRR Seri 200 dan 300 pada Tahap Pengujian. Pros. Lok. Nas. Pemuliaan Tanaman Karet. pp. 84-106(2009). 